Article

\title{
Sugar Production from Hybrid Poplar Sawdust: Optimization of Enzymatic Hydrolysis and Wet Explosion Pretreatment
}

\author{
Rajib Biswas ${ }^{1}$, Philip J. Teller ${ }^{1}$, Muhammad U. Khan ${ }^{1,2}$ and Birgitte K. Ahring ${ }^{1,2,3, *}$ \\ 1 Bioproducts, Sciences and Engineering Laboratory, Washington State University, Tri-Cities, 2710, \\ Crimson Way, Richland, WA 99354, USA; r.biswas@tricity.wsu.edu (R.B.); pt@biovantage.dk (P.J.T.); \\ muhammadusman.khan@wsu.edu (M.U.K.) \\ 2 Biological Systems Engineering, L.J. Smith Hall, Washington State University, Pullman, WA 99164, USA \\ 3 The Gene and Linda Voiland School of Chemical Engineering and Bioengineering, Washington State \\ University, Pullman, WA 99163, USA \\ * Correspondence: bka@wsu.edu; Tel.: +1-(509)-372-7682
}

Academic Editors: Ivet Ferrer, Georgia Antonopoulou, Leonidas Matsakas and Nuriye Altınay Perendeci

Received: 21 June 2020; Accepted: 20 July 2020; Published: 27 July 2020

\begin{abstract}
Wet explosion pretreatment of hybrid poplar sawdust (PSD) for the production of fermentable sugar was carried out in the pilot-scale. The effects of pretreatment conditions, such as temperature $\left(170-190{ }^{\circ} \mathrm{C}\right)$, oxygen dosage $(0.5-7.5 \%$ of dry matter $(\mathrm{DM}), w / w)$, residence time (10-30 min), on cellulose and hemicellulose digestibility after enzymatic hydrolysis were ascertained with a central composite design of the experiment. Further, enzymatic hydrolysis was optimized in terms of temperature, $\mathrm{pH}$, and a mixture of CTec2 and HTec2 enzymes (Novozymes). Predictive modeling showed that cellulose and hemicellulose digestibility of $75.1 \%$ and $83.1 \%$, respectively, could be achieved with a pretreatment at $177^{\circ} \mathrm{C}$ with $7.5 \% \mathrm{O}_{2}$ and a retention time of $30 \mathrm{~min}$. An increased cellulose digestibility of $87.1 \% \pm 0.1$ could be achieved by pretreating at $190{ }^{\circ} \mathrm{C}$; however, the hemicellulose yield would be significantly reduced. It was evident that more severe conditions were required for maximal cellulose digestibility than that of hemicellulose digestibility and that an optimal sugar yield demanded a set of conditions, which overall resulted in the maximum sugar yield.
\end{abstract}

Keywords: biorefineries; enzymatic hydrolysis; fermentable sugars; hybrid poplar; wet explosion pretreatment

\section{Introduction}

The increasing focus on greenhouse gas emissions from fossil energy production, along with the decreasing resource of fossil fuels, has increased the global interest in finding alternative resources for the production of fuel, chemicals, and materials. Lignocellulosic materials are a promising feedstock for the production of industrial chemicals, materials, as well as biofuels. In the United States, more than one billion tons of lignocellulosic biomass can be produced annually, which can be used for the production of biofuels to replace the domestic use of fossil fuels and for substituting the use of fossil fuel for producing chemicals [1]. Currently, about 370 million tons of forest residue is produced for the production of paper, energy, and other products [2]. Among the lignocellulosic biomass materials, hybrid poplar (Populus spp.) is considered a promising feedstock for the production of cellulosic biofuels due to its large genetic diversity, availability for harvest over the whole year, fast growth rate, as well as higher bulk density as compared to the herbaceous feedstock, which eases the transport and storage [3]. 
Hybrid poplar (Populus spp.) is being cultivated largely in the Pacific Northwest region of the United States and has emerged into commercial production, occupying about 50,000 acres [4]. The aboveground biomass yield of a 4 years old hybrid poplar is $11 \mathrm{MgHa}^{-1} \mathrm{year}^{-1}$ [5]. Due to its large availability, fine tissue, and lower cost, this wood is widely being used for the timber and furniture industry [6]. During the processing of this hardwood into products, a large amount of sawdust is produced [7]. This residue could potentially be a cheap and abundant feedstock for the production of biofuels. However, very few studies have been done on the use of hybrid poplar sawdust as a feedstock for biofuel production along with the potential for producing cellulosic sugars from this raw material. This material contains a mixture of bark and left-over woody materials after removal of the inner woody core for producing the specific bio-products.

Poplar sawdust (PSD) could potentially be an ideal substrate for the conversion of its carbohydrates into intermediate fermentable sugars and then for the subsequent production of fuels and chemicals, using microbial processes. This is partly due to its reduced particle size and high content of carbohydrates, such as cellulose and hemicellulose ( $70 \%)$, along with low ash content. Moreover, this feedstock is widely available at a cheaper cost and will not, in any way, compete with human or animal consumption [8,9]. However, as compared to the industrial technologies developed for the conversion of sucrose and starch-rich materials to biofuels, a pretreatment step is necessary for this type of feedstock to achieve efficient hydrolysis of the carbohydrates into fermentable sugars. During the pretreatment, the rigid structure found in the cell wall is disrupted, and the major polymers, such as cellulose, hemicellulose, and lignin, can be accessed by cellulolytic enzymes [10-14]. The content of lignin and the degree of crystallinity of cellulose are major factors, which determine the efficiency of the enzymatic hydrolysis of lignocellulosic material $[15,16]$. Therefore, different types of pretreatments, such as alkali pretreatment [16], hydrothermal treatment [17], steam explosion pretreatment [18], dilute acid pretreatment [19], irradiation pretreatment [20], wet explosion [21], organic solvent pretreatment [22], hot compressed water pretreatment [23], and ionic liquids (ILs) pretreatment [24], have been used for improving enzymatic hydrolysis. However, different pretreatments have different advantages and disadvantages, such as risks of environmental pollution, high cost of chemicals added, lower efficiency, and strict operating parameters, which not only makes the pretreatment process costly but is further reducing the feasibility of the pretreatment process to be commercialized [18].

Recently, the wet explosion pretreatment method [25,26] has been advanced to pilot scale [27], where it was shown to outperform existing thermochemical pretreatment methods for processing softwood forest residues [27] and other agricultural residues [21,28]. In the wet explosion (WEx) method, biomass is exposed to an oxidizing agent (e.g., pure oxygen, air, or $\mathrm{H}_{2} \mathrm{O}_{2}$ ) under high temperature and pressure for a total of 20 to $30 \mathrm{~min}$. Besides its effectiveness in increasing carbohydrate hydrolysis, this method offers additional advantages, such as minimal water use, no requirement for chemical recovery/detoxification, the minimum formation of degradation products, and higher lignin solubility [10,21,28-30]. Currently, hemicellulose is being fractionated by using dilute acids, bases, or enzymatic hydrolysis. But the cost of enzymatic hydrolysis limits the production of sugars from hemicellulose at the industrial scale. Besides, this additional separation step is required for the removal of the acid catalysts before the utilization of sugar monomers. However, the wet explosion pretreatment can be used for selective hydrolysis of the hemicellulose fraction of biomass. High solids concentration is beneficial for lowering the cost of pretreatment and for increasing the sugar yield after enzymatic hydrolysis. The wet explosion pretreatment process can be operated at high solids level, and enzyme hydrolysis can further be done with higher solids level of pretreated material compared to several other pretreatment methods due to the low concentrations of inhibitors developed during this pretreatment [31]. Overall, the efficacy of pretreatment is largely influenced by biomass species.

The wet explosion pretreatment has been studied widely for agricultural residues and softwoods, where it has shown promising results, but, previously, it has not been studied for hardwood. Therefore, this study is the first one where hardwood is used. The process optimization is done for maximizing the formations of cellulosic sugars from this material. The optimization will further 
focus on reducing the formation of various aldehydes formed by the degradation of monomeric sugars during the pretreatment process. The formation of these inhibitory products not only reduces the yield of sugars during pretreatment, but it also hinders the bacterial and yeast fermentation process in concentration as low as $0.25 \% w / w$ [32].

In the present study, the process parameters of WEx pretreatment was tested in a pilot-scale setup during the pretreatment of poplar sawdust. The central composite design methodology was used to design a series of experiments to evaluate the effects of the process parameters on enzymatic saccharification of pretreated poplar sawdust (PPSD). The pretreatment conditions, including temperature, the dosage of oxygen, and residence time, were statistically analyzed to identify the optimal combination of parameters by evaluating responses using response surface methodology. Further, the conditions, such as temperature and $\mathrm{pH}$, for successful enzymatic saccharification of the pretreated material with commercial enzymes were optimized. The surface hydrophobic properties of the lignocellulosic biomass slurry differ from pure cellulose, which is typically used commercially for activity testing.

\section{Results and Discussion}

\subsection{Composition of Poplar Sawdust}

The chemical composition of poplar sawdust (PSD) is shown in Table 1. The total carbohydrate content of PSD accounts for $60.9 \%$, consists of glucan, xylan, galactan, arabinan, and mannan of $41.8 \%$, $14.9 \%, 0.9 \%, 0.6 \%$, and $2.7 \%$ of the total weight (oven-dry basis), respectively. Further, PSD consists of a $3.6 \%$ acetyl group and $31.9 \%$ total lignin (acid-soluble and insoluble) on an oven-dry basis. Extractives in PSD measured in sequential extraction with both water and ethanol in which the extractives were found to be $2.1 \%$ and $3.9 \%$, respectively. While glucan and xylan contents in the poplar sawdust were found to be lower than that of milled biomass of whole hybrid poplar, as previously reported [33], the lignin content of the poplar sawdust residues was found to be higher. This could be due to the content of bark residues with higher lignin content in the poplar sawdust sample used in this study.

Table 1. Chemical composition of poplar sawdust (PSD) raw biomass.

\begin{tabular}{cc}
\hline & G/100g Dry Matter * \\
\hline Glucan & 41.8 \\
Xylan & 14.9 \\
Galactan & 0.9 \\
Arabinan & 0.6 \\
Mannan & 2.7 \\
Acetyl & 3.6 \\
Total lignin & 31.9 \\
Acid soluble lignin & 4.2 \\
Acid insoluble lignin & 27.7 \\
Total extractives & 5.9 \\
Water extractives & 2.1 \\
Ethanol extractives & 3.9 \\
\hline
\end{tabular}

* Dry matter of PSD (as received) $=95.8 \%$ of the total solids; volatile solids $=99.1 \%$; ash $=0.9 \%$ (structural inorganics $=0.6 \%$, soil $=0.3 \%)$.

\subsection{Effect of Wet Explosion Pretreatment on Poplar Sawdust}

The optimization of wet explosion (WEx) pretreatment of poplar sawdust for subsequent enzymatic hydrolysis was based on the experimental design of 17 pretreatment runs (Table 2) performed in pilot-scale, with an initial dry-solid concentration of $30 \%$. The process parameters, such as temperature $\left(\mathrm{T}, 170-190{ }^{\circ} \mathrm{C}\right)$, oxygen dosage $\left(\left[\mathrm{O}_{2}\right], 0.5-7.5 \%\right.$ of dry matter $\left.(\mathrm{DM})\right)$, and residence time $(\mathrm{t}, 10-30 \mathrm{~min})$, were treated as factors to design the experiments. To assess process variability, three runs $(8,9$, 
and 10) were executed at the central point of process parameters, i.e., $\mathrm{T}=180{ }^{\circ} \mathrm{C},\left[\mathrm{O}_{2}\right]=4 \%$ of $\mathrm{DM}$, and $\mathrm{t}=20 \mathrm{~min}$. The mean value and standard deviation of the DM content of the PSD for the central runs were $28.3 \% \pm 1.3$. DM content after the pretreatments appeared to be lower in all the pretreatments, except for the runs $3,4,7$, and 13, where DM contents were slightly above $30 \%$.

\subsubsection{Composition of the Liquid Fraction}

The composition of the liquid fraction of PSD after wet explosion pretreatment was one of the parameters examined in this study to evaluate the effects of process parameters. After the pretreatments at a high solid concentration (30\% DM), the PSD hydrolyzates resulted in a liquid containing a mixture of compounds, including monomers (glucose, xylose, galactose, arabinose, and mannose), oligomers, organic acids (e.g., acetic acid), and furans, such as hydroxymethylfurfural (HMF) and furfural. The dilute acid hydrolysis of the liquid fractions was performed to hydrolyze the oligomers into monomers and to quantify the total sugars as monomers using HPLC analysis. The concentrations of total monomeric sugars after dilute acid hydrolysis of the liquid fraction obtained from the WEx pretreatment of PSD under various conditions are shown in Table 2. Further, the degradation products as generated after pretreatment and found in the liquid phase are also reported in Table 2.

Maximum solubilization of total carbohydrate occurred in the pretreatments carried out at median temperatures $\left(\mathrm{T}=180{ }^{\circ} \mathrm{C}\right)$. The effects of other parameters on the solubilization of carbohydrates were determined by quantifying the total sugar concentration in the liquid fraction right after the pretreatment, as shown in Figure 1, at a temperature of $180^{\circ} \mathrm{C}$. As displayed in the response surface plot (Figure 1), the highest concentration of total sugars in the liquid fraction could be achieved with an oxygen loading of above $4 \%$. According to the modeled data, a residence time greater than $22 \mathrm{~min}$ had an adverse effect on the total sugar concentration of the liquid fraction, and a reduction of the overall sugar concentration was observed. This could primarily be due to the degradation of sugars into other products during longer residence times. Interestingly, the hemicellulosic sugars are found mostly in the oligomeric form in the liquid fraction; for example, the concentration of xylooligosaccharides was 2-3 times higher than for the xylose monomer. The release of hemicellulosic sugars in the form of oligomers contributes to the reduction of sugar degradation products, such as organic acids, HMF, and furfural $[34,35]$. Both cyclic and acyclic mechanisms involved in the degradation of glucose and xylose into HMF and furfural, respectively, are enhanced by the availability of free mono-sugar. Consequently, the formation of most degradation products, such as acetic acid, HMF, and furfural, in traditional dilute acid pretreatment is multiplied by several folds when compared with hydrothermal pretreatment [36]. The composition of the aforementioned degradation products found in the liquid fraction of PSD is shown in Table 2. As observed, acetyl groups from the side chain of hemicellulose were the first to be hydrolyzed at elevated temperatures, followed by arabinan and xylan. Further, an increase in acetic acid concentration in the reaction under such conditions causes further autohydrolysis of the lignocellulosic materials and improve the overall effect of temperature and residence time on biomass structural degradation [37].

In WEx, the provision of an exothermal process at temperatures above $170{ }^{\circ} \mathrm{C}$ due to the addition of oxygen not only reduced the heating requirements [26,37] but was also found to be effective in minimizing the formation of degradation products through better process efficiency at lower process severity. As expected, the highest concentrations of acetic acid, HMF, and furfural of 8.3, 0.9, and $2.2 \mathrm{~g} / 100 \mathrm{~g}$ (oven-dry basis), respectively, were found in the pretreatment carried out at the harshest conditions applied in this study $\left(\mathrm{T}=190{ }^{\circ} \mathrm{C}, \mathrm{t}=30 \mathrm{~min}\right.$, and $\left[\mathrm{O}_{2}\right]=7.5 \%$ of $\left.\mathrm{DM}\right)$. Although these degradation products are known to be inhibitory at higher concentrations for subsequent biological conversion processes [36,38], at lower concentrations, these products can be metabolized and used as a carbon source for microorganisms [39]. Interestingly, the concentration of potential inhibitors was found even under the harshest conditions applied in our study to be within the acceptable range [32] for upstream biological processes as well as downstream processing. 
Table 2. Conditions used for wet explosion (WEx) pretreatment at 30\% initial dry matter. Soluble sugars and degradation products were measured in the liquid phase after dilute acid hydrolysis.

\begin{tabular}{|c|c|c|c|c|c|c|c|c|c|c|c|c|}
\hline Run & Temp., ${ }^{\circ} \mathrm{C}$ & $\begin{array}{l}\text { Time, } \\
\text { min. }\end{array}$ & $\begin{array}{c}\mathrm{O}_{2}, \% \\
\mathrm{DM}\end{array}$ & $\begin{array}{l}\% \text { DM of } \\
\text { after WEx }\end{array}$ & $\begin{array}{l}\text { Glucose } \\
\text { (g/L) }\end{array}$ & $\begin{array}{l}\text { Xylose } \\
\text { (g/L) }\end{array}$ & $\begin{array}{l}\text { Galactose } \\
(\mathrm{g} / \mathrm{L})\end{array}$ & $\begin{array}{l}\text { Arabinose } \\
(\mathrm{g} / \mathrm{L})\end{array}$ & $\begin{array}{l}\text { Mannose } \\
(\mathrm{g} / \mathrm{L})\end{array}$ & $\begin{array}{c}\text { Acetate } \\
\text { (g/100 g DM) }\end{array}$ & $\begin{array}{c}\text { HMF }(\mathrm{g} / 100 \mathrm{~g} \\
\text { DM) }\end{array}$ & $\begin{array}{c}\text { Furfural } \\
\text { (g/100 g DM) }\end{array}$ \\
\hline 1 & 170 & 10 & 0.5 & 28.9 & 1.9 & 9.8 & 1.9 & 1.5 & 1.5 & 0.9 & 0 & 0 \\
\hline 2 & 170 & 10 & 7.5 & 29.1 & 2.8 & 21.0 & 3.2 & 2.5 & 2.7 & 1.2 & 0 & 0 \\
\hline 3 & 170 & 20 & 4.0 & 30.1 & 3.0 & 29.5 & 3.9 & 2.3 & 3.7 & 1.7 & 0 & 0.1 \\
\hline 4 & 170 & 30 & 0.5 & 31.5 & 2.6 & 23.7 & 2.8 & 1.4 & 3.5 & 1.5 & 0 & 0.2 \\
\hline 5 & 170 & 30 & 7.5 & 25.7 & 4.4 & 34.3 & 4.1 & 1.8 & 5.7 & 3.0 & 0 & 0.4 \\
\hline 6 & 180 & 10 & 4.0 & 29.2 & 2.8 & 26.4 & 3.5 & 1.4 & 3.5 & 1.5 & 0 & 0.1 \\
\hline 7 & 180 & 20 & 0.5 & 30.2 & 2.8 & 28.9 & 2.9 & 1.3 & 3.6 & 2.0 & 0 & 0.4 \\
\hline 8 (central) & 180 & 20 & 4.0 & 27.0 & 3.9 & 33.7 & 3.8 & 1.8 & 5.7 & 3.1 & 0.1 & 0.5 \\
\hline 9 (central) & 180 & 20 & 4.0 & 29.5 & 3.6 & 31.2 & 3.5 & 1.7 & 5.2 & 3.0 & 0.1 & 0.6 \\
\hline 10 (central) & 180 & 20 & 4.0 & 28.3 & 4.0 & 31.9 & 3.7 & 1.8 & 5.6 & 3.1 & 0.1 & 0.6 \\
\hline 11 & 180 & 20 & 7.5 & 28.4 & 7.0 & 32.7 & 3.8 & 1.8 & 6.7 & 4.8 & 0.2 & 1.0 \\
\hline 12 & 180 & 30 & 4.0 & 28.6 & 6.7 & 33.1 & 4.0 & 1.8 & 7.4 & 6.3 & 0.3 & 1.2 \\
\hline 13 & 190 & 10 & 0.5 & 30.7 & 3.5 & 33.0 & 3.6 & 1.3 & 4.9 & 2.6 & 0.1 & 0.5 \\
\hline 14 & 190 & 10 & 7.5 & 28.2 & 5.0 & 32.6 & 3.7 & 1.7 & 6.3 & 3.7 & 0.1 & 0.6 \\
\hline 15 & 190 & 20 & 4.0 & 26.9 & 6.0 & 25.0 & 3.2 & 1.5 & 6.8 & 5.3 & 0.3 & 1.5 \\
\hline 16 & 190 & 30 & 0.5 & 26.6 & 4.0 & 19.4 & 2.6 & 1.4 & 5.6 & 5.3 & 0.3 & 1.8 \\
\hline 17 & 190 & 30 & 7.5 & 27.5 & 13.0 & 9.0 & 1.9 & 1.2 & 5.0 & 8.3 & 0.9 & 2.2 \\
\hline
\end{tabular}






Figure 1. The concentration of total monomeric sugars after the dilute acid hydrolysis of the liquid fraction obtained after wet explosion pretreatment of poplar sawdust at median temperature $\left(180{ }^{\circ} \mathrm{C}\right)$ at different $\mathrm{O}_{2}$ concentration and residence time.

\subsubsection{Enzymatic Hydrolysis of Pretreated Poplar Sawdust}

The pretreated poplar sawdust samples were digested with a mixture of enzymes (Cellic ${ }^{\circledR} \mathrm{CTec} 2$ and Cellic ${ }^{\circledR}$ HTec 2 kindly provided by Novozymes, Franklinton, NC, USA) at initial enzyme dosages of $16.7 \mathrm{mg}$ enzyme proteins (EP)/g DM, of which $11.7 \mathrm{mg}$ EP from CTec2 (mainly cellulolytic activity) and $5.0 \mathrm{mg}$ EP from HTec2 (mainly hemicellulolytic activity), were applied for all the pretreated samples and monitored for cellulose digestibility. These commercial enzymes are capable of hydrolyzing the carbohydrate polymers into monomeric solutions, while the non-digestible compounds, such as lignin, remain as an insoluble residue. The efficiency of the pretreatment for lignocellulosic biomass can be evaluated based on the sugar yields after enzymatic hydrolysis $[21,33]$. The cellulose digestibility after the enzymatic hydrolysis of pretreated PSD at different residence times (10-30 min) was calculated from the percentage of glucan obtained after the hydrolysis of original glucan input [21]. In the initial screening of pretreated samples, the highest glucan yield of $87.1 \% \pm 0.1$ was obtained under pretreatment performed at $190{ }^{\circ} \mathrm{C}$ with $30 \mathrm{~min}$ residence time and $7.5 \% \mathrm{O}_{2}$ of DM (run\#17). Figure 2 depicts the response surface model of cellulose digestibility after the enzymatic hydrolysis of pretreated PSD. All the parameters tested in this study had an influence on the glucan yield, while the temperature was the key factor. It is apparent that the impact of temperature on cellulose digestibility increases with the increase in the concentration of $\mathrm{O}_{2}$ regardless of the residence time. With the same temperature of $190{ }^{\circ} \mathrm{C}$, cellulose digestibility increased from $56.5 \% \pm 0$ in run 13 to $87.1 \% \pm 0.1$ in run 17 , with an increase in $\mathrm{O}_{2}$ concentration from $0.5 \%$ to $7.5 \%$ at $30 \mathrm{~min}$ residence time. However, the hemicellulose digestibility/yield was found to be significantly lower in run $17(32.7 \% \pm 0)$. This could be due to the fact that increasing the pretreatment severity would result in increased degradation of hemicellulosic sugar. On the other hand, the maximum hemicellulose digestibility of $90.8 \% \pm 0$ was achieved in run 5 with a temperature of $170{ }^{\circ} \mathrm{C}, 7.5 \% \mathrm{O}_{2}$ concentration, and $30 \mathrm{~min}$ residence time. The results for each response of cellulose digestibility and hemicellulose digestibility with the predicted $p$-values $(p<0.0001)$ and the coefficient of determination $\left(\mathrm{R}^{2}\right)$ are depicted with the fitted correlation of actual and predicted values in Figure 3. The prediction model for both cellulose digestibility and hemicellulose digestibility after enzymatic hydrolysis showed a satisfying correlation coefficient $\left(R^{2}=0.97\right)$. The maximum desirability (0.76) in the predictive model showed a cellulose digestibility of $75.1 \%$ and hemicellulose digestibility of $83.1 \%$, which were achieved at a temperature of $177^{\circ} \mathrm{C}$ with $7.5 \% \mathrm{O}_{2}$ concentration and $30 \mathrm{~min}$ residence time. Although this cellulose digestibility (75.1\%) was lower than the values obtained in 
optimal conditions for cellulose hydrolysis, nonetheless, the cellulose digestibility (75.1\%) found in this study was still higher than the values obtained by Kim et al. [40] on hybrid poplar using liquid hot water pretreatment at $200{ }^{\circ} \mathrm{C}$ for $10 \mathrm{~min}$ at $15 \%$ solids. In their studies [40], total monomeric sugar yield (glucose and xylose) reached $67 \%$ after 72 h of hydrolysis when 40 Filter Paper Units (FPU) cellulase per gram glucan was used, which is significantly higher enzyme loadings compared to our study. With 15 FPU cellulase per gram glucan, the glucose yield was only $54 \%$ after 120 h of enzymatic hydrolysis [40]. The results of cellulose and hemicellulose digestibility are comparable with other lignocellulosic feedstocks pretreated by wet explosion pretreatment, as shown in Table 3.
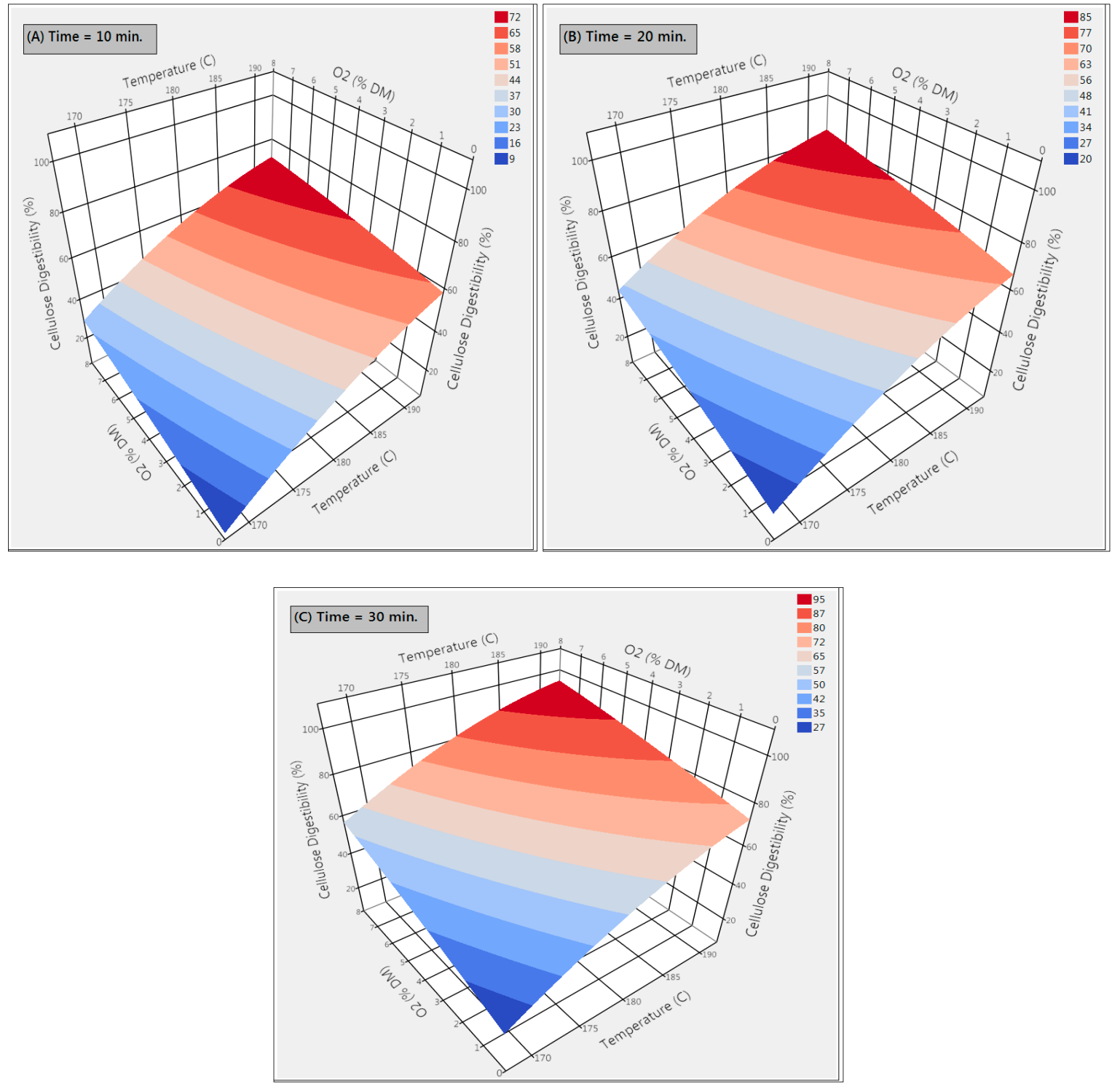

Figure 2. Response surface plots, showing the influence of temperature and residence time on cellulose digestibility (\%) after enzymatic hydrolysis of pretreated poplar sawdust at different residence times; (A) residence time $10 \mathrm{~min}$; (B) residence time $20 \mathrm{~min}$; (C) residence time $30 \mathrm{~min}$. 
Table 3. Comparison of biomass digestibility with other feedstock pretreated by wet explosion pretreatment.

\begin{tabular}{|c|c|c|c|}
\hline Feedstock & Pretreatment Conditions & Digestibility & Reference \\
\hline Sugarcane bagasse & $185^{\circ} \mathrm{C}, 10 \mathrm{~min}, 16 \%$ of $\mathrm{DM}$ & $87 \%$ cellulose & [21] \\
\hline Loblolly pine & $170{ }^{\circ} \mathrm{C}, 22 \mathrm{~min}, 25 \%$ of $\mathrm{DM}$ & $96 \%$ cellulose and nearly, $100 \%$ hemicellulose & [31] \\
\hline Wheat straw & $180-185^{\circ} \mathrm{C}, 15 \mathrm{~min}, 14 \%$ of $\mathrm{DM}$ & $70 \%$ cellulose, $68 \%$ hemicellulose & [41] \\
\hline Wheat straw & $180-185^{\circ} \mathrm{C}, 15 \mathrm{~min}, 14 \%$ of $\mathrm{DM}$ & $69 \%$ cellulose, $55 \%$ hemicellulose & [41] \\
\hline Miscanthus & $170{ }^{\circ} \mathrm{C}, 5 \mathrm{~min}, 15 \%$ of $\mathrm{DM}$ & $56 \%$ glucose, $32 \%$ xylose & [42] \\
\hline Winter rye straw & $195^{\circ} \mathrm{C}, 15 \mathrm{~min}, 6 \%$ of $\mathrm{DM}$ & $49 \%$ cellulose, $11 \%$ hemicellulose & [43] \\
\hline Oilseed rape straw & $195^{\circ} \mathrm{C}, 15 \mathrm{~min}, 6 \%$ of $\mathrm{DM}$ & $58 \%$ cellulose, $10 \%$ hemicellulose & [43] \\
\hline Faba bean straw & $195^{\circ} \mathrm{C}, 15 \mathrm{~min}, 6 \%$ of $\mathrm{DM}$ & $43 \%$ cellulose, $10 \%$ hemicellulose & [43] \\
\hline hybrid poplar sawdust & $177^{\circ} \mathrm{C}, 30 \mathrm{~min}, 7.5 \% \mathrm{O}_{2}, 30 \%$ of $\mathrm{DM}$ & $75.1 \%$ Cellulose, $83.1 \%$ hemicellulose & This study \\
\hline
\end{tabular}



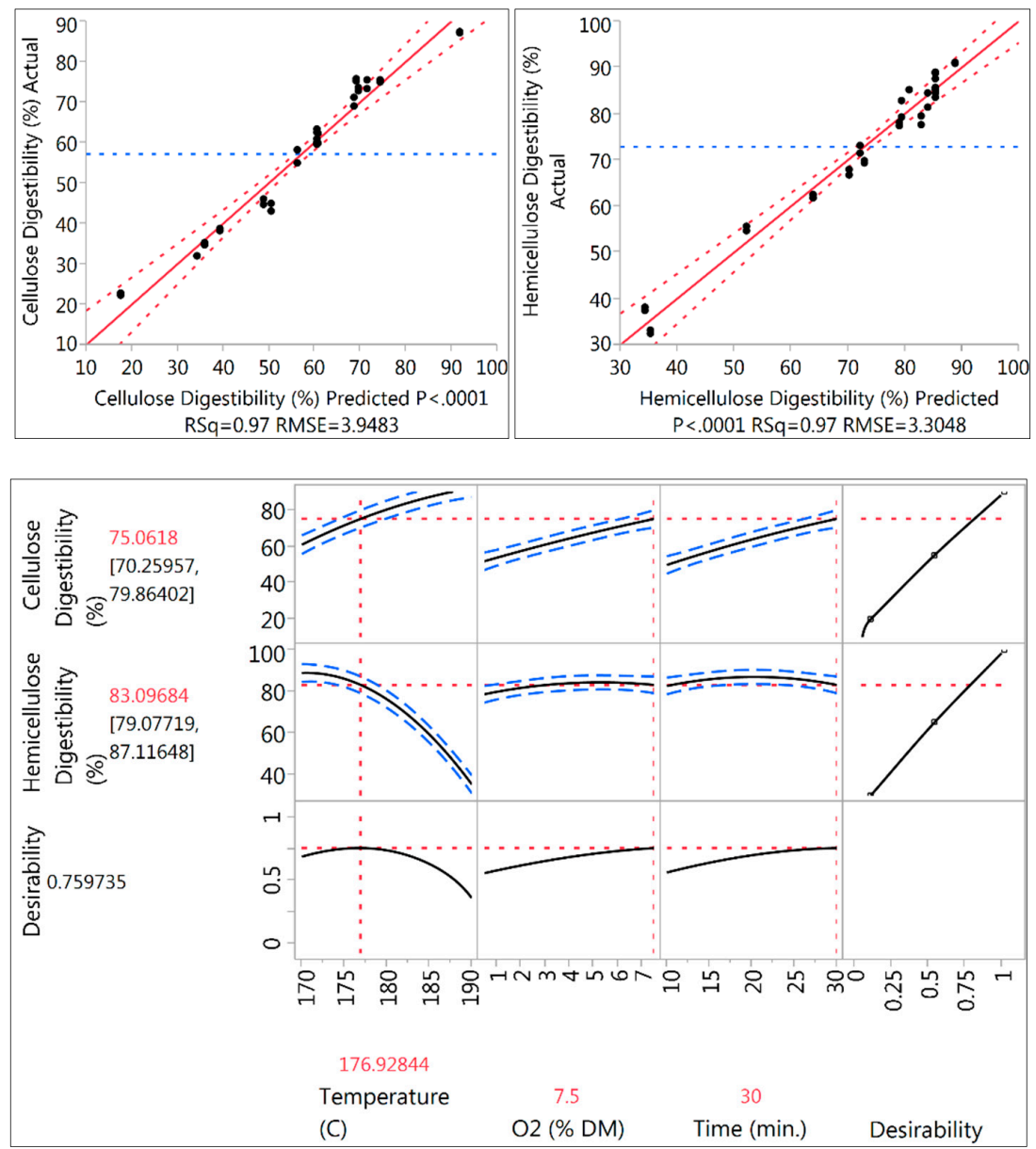

Figure 3. Fitted correlation of actual and predicted values, showing cellulose digestibility and hemicellulose digestibility with $p$-values and the coefficient of determination $\left(\mathrm{R}^{2}\right)$. The maximum desirability in the predictive model is showing the cellulose digestibility and hemicellulose digestibility under different pretreatment conditions and with an optimal set of conditions.

\subsubsection{Enzymatic Hydrolysis Optimization}

The enzymatic hydrolysis conditions, such as temperature, $\mathrm{pH}$, and $\mathrm{CTec} 2 / \mathrm{HTec} 2$ ratio, were screened to determine the effects of the parameters on glucose yields. Typically, pure cellulose is used as a substrate to evaluate the optimal conditions for enzymatic saccharification. However, the surface hydrophobic properties of pure cellulose differ significantly from lignocellulosic biomass, especially after lignocellulosic biomass undergoes thermochemical pretreatment under elevated temperatures. It was also previously shown that $\mathrm{pH}$ has an effect on the amounts of cellulases, which are bound productively to cellulose, making up a fraction that does not participate in cellulose hydrolysis due to nonproductive attachment with lignin [44]. PPSD sample obtained in run 17 was digested with a mixture of enzymes, (Cellic ${ }^{\circledR}$ CTec2 and Cellic ${ }^{\circledR}$ HTec2) with 3 different ratios (4:0, 3:1, and 2:2) at a total of $8.4 \mathrm{mg} \mathrm{EP} / \mathrm{g}$ $\mathrm{DM}$, was tested in a temperature range between $40^{\circ} \mathrm{C}$ and $55^{\circ} \mathrm{C}$ and a $\mathrm{pH}$ range between 4.5 and 5.5, and incubated for $72 \mathrm{~h}$. The low enzyme dosage was chosen to closely observe the effect of the variable conditions applied. As shown in Figure 4, the maximum cellulose digestibility could be achieved using the mixture of enzymes of $\mathrm{CTec} 2$ and $\mathrm{HTec} 2$ with a ratio of 3:1 under the conditions of pH 5.5 and hydrolysis temperature of $47.4{ }^{\circ} \mathrm{C}$. According to the statistical analysis, the desirability of 0.973 could be achieved using the set of conditions for enzymatic hydrolysis. Overall, using this optimal set of conditions for enzymatic hydrolysis, the cellulose digestibility of pretreated poplar sawdust could be further enhanced by $8.4 \%$ on top of the achieved sugar yields while using the recommended conditions from the enzyme provider. 

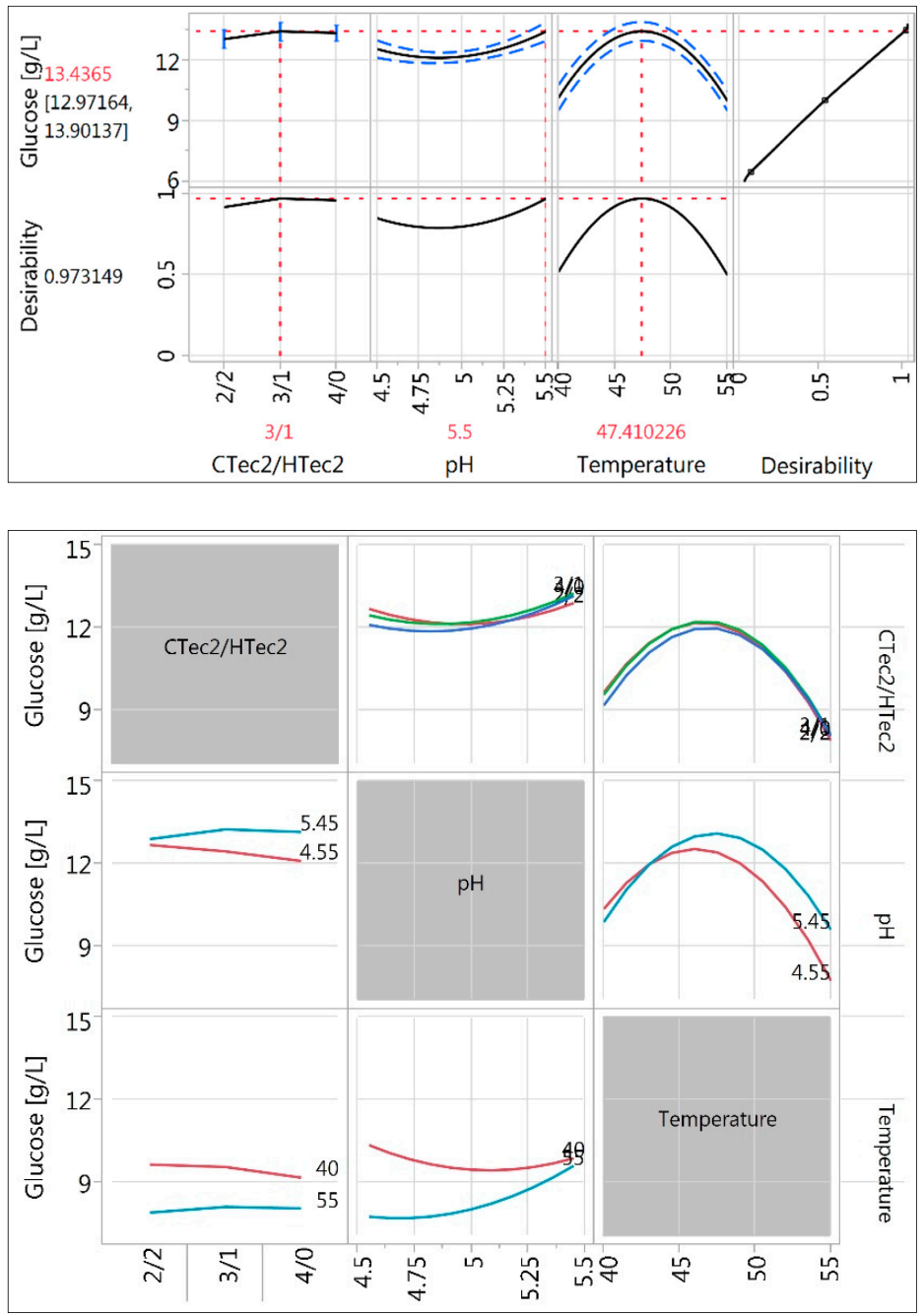

Figure 4. The maximum desirability, showing glucose concentration at the specific set of conditions for the enzymatic hydrolysis. The effects of individual variability of glucose concentration as a result of enzymatic hydrolysis under different conditions are shown.

\section{Materials and Methods}

\subsection{Raw Materials}

Hybrid poplar (Populus spp.) sawdust (PSD) used in the study was obtained from Upper Columbia Mill (UCM) in Boardman, OR, USA, processing lumber products. The original poplar sawdust dry matter (DM) was determined to be $95.8 \%$ (volatile solids $=99.1 \%$ of total solids $(\mathrm{TS})$; ash $=0.9 \%$ ). The poplar sawdust was powdery with a particle size of $2-4 \mathrm{~mm}$ and was used as obtained without further size reduction. The chemical composition is shown in Table 1.

\subsection{Compositional Analysis}

The moisture, carbohydrates, acid-insoluble lignin (Klason lignin), acid-soluble lignin, and ash contents of original raw materials were determined by analytical procedures developed by the National Renewable Energy Laboratory (NREL) $[45,46]$. The first stage hydrolysis of $0.3 \mathrm{~g}$ samples of biomass was performed with $3.0 \mathrm{~mL}$ of $72 \%(w / w) \mathrm{H}_{2} \mathrm{SO}_{4}$ for $1 \mathrm{~h}$ at $30^{\circ} \mathrm{C}$ in a water bath. The $84 \mathrm{~mL}$ of deionized water (DI) was added to dilute the hydrolyzates to $4 \% \mathrm{H}_{2} \mathrm{SO}_{4}(w / w)$ concentration and autoclaved at $121^{\circ} \mathrm{C}$ for $1 \mathrm{~h}$. Sugar monomers were analyzed on an Aminex HPX-87H column (Bio-Rad, Hercules, CA, USA) at $60{ }^{\circ} \mathrm{C}$ with $4 \mathrm{mmol} \mathrm{H}_{2} \mathrm{SO}_{4}$ as eluent with a flow rate of $0.6 \mathrm{~mL} / \mathrm{min}$. Composition analysis was carried out in triplicates, and sugar contents were quantified by comparison with sugar calibration standards. 


\subsection{Wet Explosion Pretreatment}

The wet explosion pretreatment (WEx) of poplar sawdust was performed in a pilot-scale set-up that includes a $100 \mathrm{~L}$ stainless steel pressure reactor equipped with an anchor-shaped scraper type mixer. The target temperature was reached by direct steam injection, replacing residual air in the headspace. The mixing speed of $50 \mathrm{rpm}$ was maintained during the heating period (approx. $10 \mathrm{~min}$ ). The final temperature was maintained with an external oil heater until the reaction was terminated. Oxygen was purged into the reactor, and an elevated mixing speed of $75 \mathrm{rpm}$ was applied. After the predetermined residence time, the reaction was terminated by opening the discharge valve into a 250 L flash tank, initiating a sudden decompression of the materials in the reactor. In each run, the $100 \mathrm{~L}$ pretreatment reactor was impregnated with $4 \mathrm{~kg}$ (oven-dry basis) of poplar sawdust, and tap water was added to reach a solid concentration of $30 \%$. The pretreatment conditions applied for the series of runs are shown in Table 2. A sample was collected to carry out liquid analysis for sugars, organic acids, and furans. Enzymatic hydrolysis experiments were conducted on pretreated slurry without any solid-liquid separation to minimize process steps.

\subsection{Design of Experiment}

The wet explosion pretreatments of PSD were performed at temperatures ranged from $170-190^{\circ} \mathrm{C}$ based on the preliminary experiments and available literature data [21,27]. Oxygen dosage used in this study varied in the range of $0.5-7.5 \%$ of DM (dry matter, $w / w)$, with a residence time of 10-30 min. A central composite design (Table 2), including three central points of the factors, was used to design the experiments. A series of 17 runs with different operational conditions was suggested in order to generate regression reports of the factors and responses using response surface methodology. The yields of glucan, xylan, and total carbohydrate after the enzymatic hydrolysis of the pretreated samples were determined to evaluate the optimal set of parameters for the pretreatment. In addition, monomeric and oligomeric sugars, acetic acid, and furans (5-hydroxymethylfurfural and furfural) were further evaluated.

\subsection{Analysis of Liquid Fraction after Pretreatment}

The liquid fraction of pretreated poplar sawdust (PPSD) from each pretreatment run was analyzed for monosaccharides (glucose, xylose, and arabinose), acetic acid, 5-hydroxymethylfurfural (HMF), and furfural by an HPLC system equipped with an Aminex HPX-87H column (Bio-Rad, Hercules, CA, USA), as described in compositional analysis subsection. The acid hydrolysis of the liquid was carried in Eppendorf tubes using $4 \% \mathrm{H}_{2} \mathrm{SO}_{4}(w / w)$ at $99{ }^{\circ} \mathrm{C}$ for $4 \mathrm{~h}$ and neutralized using an equivalent amount of barium hydroxide. Dilute acid hydrolysis of the liquid samples was carried out in triplicates, and the samples were always filtered using a $0.45 \mu \mathrm{m}$ filter (PTFE membrane, Acrodisc ${ }^{\circledR}$ syringe filters, $13 \mathrm{~mm}$, Pall $^{\circledR}$ Life Sciences, Pensacola, FL, USA) before chromatographic analysis.

\subsection{Enzymatic Hydrolysis}

Enzymatic hydrolysis of PPSD samples was performed with a mixture of Cellic ${ }^{\circledR}$ CTec2 and Cellic ${ }^{\circledR}$ HTec2 (Novozymes, Franklinton, NC, USA). Initial enzyme dosages of 16.7 mg enzyme proteins (EP)/g DM, of which $11.7 \mathrm{mg}$ EP from CTec2 and $5.0 \mathrm{mg}$ EP from HTec2, were applied for all the pretreated samples. The enzyme proteins of CTec2 and HTec2 were determined to be 265 and $235 \mathrm{mg} \mathrm{EP} / \mathrm{mL}$, respectively, using Pierce ${ }^{\circledR}$ BCA ${ }^{\circledR}$ protein assay kit following the company's procedure (Thermo-Fisher Scientific, Rockford, IL, USA). Five grams of oven-dry substrate were supplemented with $5 \mathrm{~mL} 1 \mathrm{M}$ citrate buffer $(\mathrm{pH}=5.0)$ and aforementioned enzyme mixtures and then added into DI water to achieve a $5 \%(w / w)$ consistency of solution. One milliliter of sodium azide solution $(2 \%, w / w)$ was used in the media to inhibit microbial contamination. However, $5 \%$ consistency of solution with enzyme dosages of a total of only $8.4 \mathrm{mg} \mathrm{EP} / \mathrm{g} \mathrm{DM}$ was used in order to optimize the enzymatic hydrolysis conditions, such as $\mathrm{pH}$, temperature, and enzyme mixtures, incubated at 
$50{ }^{\circ} \mathrm{C}$. Enzymatic hydrolysis optimization experiments were carried out at $40 / 45 / 50 / 55^{\circ} \mathrm{C}$, according to experimental design, in an incubator shaker (the lab companion IS-971 [R/RF] floor model incubated shaker, Jeiotech Co. Ltd., Daejeon, Korea) at $180 \mathrm{rpm}$ for $72 \mathrm{~h}$. After the enzymatic hydrolysis, the hydrolyzate sample was centrifuged at relative centrifugal force (RCF) of $20,817 \times g$ for $10 \mathrm{~min}$ at $4{ }^{\circ} \mathrm{C}$ and filtered $(0.45 \mathrm{~mm})$ for HPLC analysis. All the experiments were performed in duplicate using $250 \mathrm{~mL}$ screw cap glass vial with an active volume of $100 \mathrm{~mL}$. Reported values were corrected for the sugar contribution from the enzyme mixture, as found in the blanks.

\subsection{Statistical Data Analysis}

The design of experiments and the experimental data were analyzed using JMP Pro statistical software (SAS, version 11.0). Total solubilized carbohydrates, organic acids, HMF, and furfural in liquid fraction and as post-pretreatment responses were assessed. Further, the yields of predominant sugars-glucan and xylan - in terms of cellulose and hemicellulose digestibility after the enzymatic hydrolysis were evaluated as responses of the examined factors (temperature, time, and oxygen dosage). The analysis was carried out in a fitted correlation using second-degree interaction under response surface macros and standard least-square personality with an emphasis on effect leverage.

\section{Conclusions}

This was the first time that WEx was used to pretreat poplar sawdust. In this study, we optimized the wet explosion pretreatment conditions for poplar sawdust for the optimum production of fermentable sugars. After the enzymatic hydrolysis, the highest total sugar yields (from the conversion of $75.1 \%$ cellulosic and $83.1 \%$ hemicellulosic) could be achieved at pretreatment conditions of $177^{\circ} \mathrm{C}$ with $7.5 \%$ $\mathrm{O}_{2}$ and 30 min residence time. However, cellulosic sugar yield increased with up to $87.1 \%$ by using an operational temperature of $190^{\circ} \mathrm{C}$. However, the hemicellulosic sugar yield would decrease in these conditions compared to the use of lower temperatures, and sugar yield of $90.8 \%$ for the hemicellulose fraction could be achieved at $170^{\circ} \mathrm{C}$. Furthermore, the overall cellulose digestibility could be enhanced by $8.4 \%$ when using CTec2:HTec2 in a 3:1 relation at $47.4{ }^{\circ} \mathrm{C}$ and $\mathrm{pH} 5.5$, which is different from the conditions described as optimal by Novozymes, the enzyme provider.

Author Contributions: Conceptualization, R.B., P.J.T., B.K.A.; methodology, R.B., P.J.T.; validation, B.K.A., P.J.T.; formal analysis, R.B., P.J.T., M.U.K.; investigation, B.K.A.; Software, R.B. and P.J.T.; data curation, R.B., B.K.A., M.U.K.; writing, R.B., M.U.K., B.K.A. All authors have read and agreed to the published version of the manuscript.

Funding: The work was funded by USDA's NARA project.

Acknowledgments: The authors would like to thank Justin Fry for his help with the pretreatment and hydrolysis experiments. Further, we thank Bruce Summers and Andrew Rodstrom of GreenWood Resources (Boardman and Clatskanie, Oregon), for their help by providing poplar sawdust woody biomass that has been used in the study.

Conflicts of Interest: The authors declare no conflict of interest. The funding agent had no role in the design of the study; in the collection, analyses, or interpretation of data; in the writing of the manuscript, or in the decision to publish the results.

\section{References}

1. Bond, J.Q.; Upadhye, A.A.; Olcay, H.; Tompsett, G.A.; Jae, J.; Xing, R.; Alonso, D.M.; Wang, D.; Zhang, T.; Kumar, R.; et al. Production of renewable jet fuel range alkanes and commodity chemicals from integrated catalytic processing of biomass. Energy Environ. Sci. 2014, 7, 1500-1523. [CrossRef]

2. Behera, S.S.; Ray, R.C. Forest bioresources for bioethanol and biodiesel production with emphasis on mohua (Madhuca latifolia L.) flowers and seeds. In Bioethanol Production from Food Crops; Academic Press: Cambridge, MA, USA, 2019; pp. 233-247.

3. Sannigrahi, P.; Ragauskas, A.J.; Tuskan, G.A. Poplar as a feedstock for biofuels: A review of compositional characteristics. Biofuel. Bioprod. Biorefin. 2010, 4, 209-226. [CrossRef]

4. Stanton, B.; Eaton, J.; Johnson, J.; Rice, D.; Schuette, B.; Moser, B. Hybrid poplar in the Pacific Northwest: The effects of market-driven management. J. For. Res. 2002, 100, 28-33. 
5. Hansen, E. Mid-Rotation Yields of Biomass Plantations in the North Central US; Research Paper NC-309; US Dept. of Agriculture, Forest Service, North Central Forest Experiment Station: St. Paul, MN, USA, 1992; p. 309.

6. Benomar, L.; DesRochers, A.; Larocque, G.R. Comparing growth and fine root distribution in monocultures and mixed plantations of hybrid poplar and spruce. J. For. Res. 2013, 24, 247-254. [CrossRef]

7. Hamelinck, C.N.; Van Hooijdonk, G.; Faaij, A.P. Ethanol from lignocellulosic biomass: Techno-economic performance in short-, middle-and long-term. Biomass Bioenergy 2005, 28, 384-410. [CrossRef]

8. Cornejo, A.; Alegria-Dallo, I.; García-Yoldi, Í.; Sarobe, Í.; Sánchez, D.; Otazu, E.; Martínez-Merino, V. Pretreatment and enzymatic hydrolysis for the efficient production of glucose and furfural from wheat straw, pine and poplar chips. Bioresour. Technol. 2019, 121583. [CrossRef]

9. De Bhowmick, G.; Sarmah, A.K.; Sen, R. Lignocellulosic biorefinery as a model for sustainable development of biofuels and value-added products. Bioresour. Technol. 2018, 247, 1144-1154. [CrossRef]

10. Khan, M.U.; Ahring, B.K. Lignin degradation under anaerobic digestion: Influence of lignin modificationsA review. Biomass Bioenergy 2019, 128, 105325. [CrossRef]

11. Bär, J.; Phongpreecha, T.; Singh, S.K.; Yilmaz, M.K.; Foster, C.E.; Crowe, J.D.; Hodge, D.B. Deconstruction of hybrid poplar to monomeric sugars and aromatics using ethanol organo-solvent fractionation. Biomass Convers. Biorefin. 2018, 8, 813-824. [CrossRef]

12. Rubin, E.M. Genomics of cellulosic biofuels. Nature 2008, 454, 841-845. [CrossRef]

13. Takada, M.; Chandra, R.P.; Saddler, J.N. The influence of lignin migration and relocation during steam pretreatment on the enzymatic hydrolysis of softwood and corn stover biomass substrates. Biotechnol. Bioeng. 2019, 116, 2864-2873. [CrossRef] [PubMed]

14. Kellock, M.; Maaheimo, H.; Marjamaa, K.; Rahikainen, J.; Zhang, H.; Holopainen-Mantila, U.; Kruus, K. Effect of hydrothermal pretreatment severity on lignin inhibition in enzymatic hydrolysis. Bioresour. Technol. 2019, 280, 303-312. [CrossRef] [PubMed]

15. Ahring, B.K.; Alapuranen, M.; Berlin, A.; Bura, R.; Chandra, R.P.; Cherry, J.; Galbe, M.; Gorwa-Grauslund, M.F.; Grabar, T.B.; den Haan, R.; et al. Fueling industrial biotechnology growth with bioethanol. Biofuels Adv. Biochem. Eng. Biotechnol. 2007, 108, 1-40.

16. Cai, L.Y.; Ma, Y.L.; Ma, X.X.; Lv, J.M. Improvement of enzymatic hydrolysis and ethanol production from corn stalk by alkali and N-methylmorpholine-N-oxide pretreatments. Bioresour. Technol. 2016, 212, 42-46. [CrossRef] [PubMed]

17. Manzanares, P.; Ballesteros, I.; Negro, M.J.; González, A.; Oliva, J.M.; Ballesteros, M. Processing of extracted olive oil pomace residue by hydrothermal or dilute acid pretreatment and enzymatic hydrolysis in a biorefinery context. Renew. Energy 2020, 145, 1235-1245. [CrossRef]

18. Liu, Z.H.; Chen, H.Z. Periodic peristalsis enhancing the high solids enzymatic hydrolysis performance of steam exploded corn stover biomass. Biomass Bioenergy 2016, 93, 13-24. [CrossRef]

19. Jeong, H.S.; Jang, S.K.; Kim, H.Y.; Yeo, H.; Choi, J.W.; Choi, I.G. Effect of freeze storage on hemicellulose degradation and enzymatic hydrolysis by dilute-acid pretreatment of Mongolian oak. Fuel 2016, 165, 145-151. [CrossRef]

20. Yin, Y.; Wang, J. Enhancement of enzymatic hydrolysis of wheat straw by gamma irradiation-alkaline pretreatment. Radiat. Phys. Chem. 2016, 123, 63-67. [CrossRef]

21. Biswas, R.; Uellendahl, H.; Ahring, B.K. Wet explosion pretreatment of sugarcane bagasse for enhanced enzymatic hydrolysis. Biomass Bioenergy 2014, 61, 104-113. [CrossRef]

22. Zhou, Z.; Xue, W.; Lei, F.; Cheng, Y.; Jiang, J.; Sun, D. Kraft GL-ethanol pretreatment on sugarcane bagasse for effective enzymatic hydrolysis. Ind. Crops Prod. 2016, 90, 100-109. [CrossRef]

23. Hideno, A.; Inoue, H.; Yanagida, T.; Tsukahara, K.; Endo, T.; Sawayama, S. Combination of hot compressed water treatment and wet disk milling for high sugar recovery yield in enzymatic hydrolysis of rice straw. Bioresour. Technol. 2012, 104, 743-748. [CrossRef]

24. Hou, X.; Wang, Z.; Sun, J.; Li, M.; Wang, S.; Chen, K.; Gao, Z. A microwave-assisted aqueous ionic liquid pretreatment to enhance enzymatic hydrolysis of Eucalyptus and its mechanism. Bioresour. Technol. 2019, 272, 99-104. [CrossRef] [PubMed]

25. Ahring, B.K.; Munck, J. Method for Treating Biomass and Organic Waste with the Purpose of Generating Desired Biologically Based Products. U.S. Patent 20090178671A1, 16 July 2009.

26. Merrill, R.A.; Petersen, K. Wet Oxidation of Biomass. U.S. Patent 20140199740A1, 17 July 2014.

27. Biswas, R.; Teller, P.J.; Ahring, B.K. Pretreatment of forest residues of Douglas fir by wet explosion for enhanced enzymatic saccharification. Bioresour. Technol. 2015, 192, 46-53. [CrossRef] [PubMed] 
28. Khan, M.U.; Ahring, B.K. Anaerobic digestion of biorefinery lignin: Effect of different wet explosion pretreatment conditions. Bioresour. Technol. 2020, 298, 122537. [CrossRef] [PubMed]

29. Biswas, R.; Ahring, B.K.; Uellendahl, H. Improving biogas yields using an innovative concept for conversion of the fiber fraction of manure. Water Sci. Technol. 2012, 66, 1751-1758. [CrossRef] [PubMed]

30. Ahring, B.K.; Biswas, R.; Ahamed, A.; Teller, P.J.; Uellendahl, H. Making lignin accessible for anaerobic digestion by wet-explosion pretreatment. Bioresour. Technol. 2015, 175, 182-188.

31. Rana, D.; Rana, V.; Ahring, B.K. Producing high sugar concentrations from loblolly pine using wet explosion pretreatment. Bioresour. Technol. 2012, 121, 61-67. [CrossRef]

32. Palmqvist, E.; Grage, H.; Meinander, N.Q.; Hahn-Hägerdal, B. Main and interaction effects of acetic acid, furfural, and p-hydroxybenzoic acid on growth and ethanol productivity of yeasts. Biotechnol. Bioeng. 1999, 63, 46-55. [CrossRef]

33. Dai, J.; McDonald, A.G. Production of fermentable sugars and polyhydroxybutyrate from hybrid poplar: Response surface model optimization of a hot-water pretreatment and subsequent enzymatic hydrolysis. Biomass Bioenergy 2014, 71, 275-284. [CrossRef]

34. Mosier, N.; Wyman, C.; Dale, B.; Elander, R.; Lee, Y.Y.; Holtzapple, M.; Ladisch, M. Features of promising technologies for pretreatment of lignocellulosic biomass. Bioresour. Technol. 2005, 96, 673-686. [CrossRef]

35. ATW, M.H.; Zeeman, G. Pretreatments to enhance the digestibility of lignocellulosie biomass. Bioresour. Technol. 2009, 100, 10-18.

36. Rasmussen, H.; Sørensen, H.R.; Meyer, A.S. Formation of degradation compounds from lignocellulosic biomass in the biorefinery: Sugar reaction mechanisms. Carbohydr. Res. 2014, 385, 45-57. [CrossRef] [PubMed]

37. Biswas, R.; Uellendahl, H.; Ahring, B.K. Wet explosion: A universal and efficient pretreatment process for lignocellulosic biorefineries. Bioenergy Res. 2015, 8, 1101-1116. [CrossRef]

38. Palmqvist, E.; Hahn-Hägerdal, B. Fermentation of lignocellulosic hydrolysates. II: Inhibitors and mechanisms of inhibition. Bioresour. Technol. 2000, 74, 25-33. [CrossRef]

39. Biswas, R.; Uellendahl, H.; Ahring, B.K. Conversion of C6 and C5 sugars in undetoxified wet exploded bagasse hydrolysates using Scheffersomyces (Pichia) stipitis CBS6054. AMB Express 2013, 3, 42. [CrossRef]

40. Kim, Y.; Mosier, N.S.; Ladisch, M.R. Enzymatic digestion of liquid hot water pretreated hybrid poplar. Biotechnol. Prog. 2009, 25, 340-348. [CrossRef]

41. Georgieva, T.I.; Hou, X.; Hilstrøm, T.; Ahring, B.K. Enzymatic hydrolysis and ethanol fermentation of high dry matter wet-exploded wheat straw at low enzyme loading. In Biotechnology for Fuels and Chemicals; Humana Press: Totowa, NJ, USA, 2007; pp. 553-562.

42. Sørensen, A.; Teller, P.J.; Hilstrøm, T.; Ahring, B.K. Hydrolysis of Miscanthus for bioethanol production using dilute acid presoaking combined with wet explosion pre-treatment and enzymatic treatment. Bioresour. Technol. 2008, 99, 6602-6607. [CrossRef]

43. Petersson, A.; Thomsen, M.H.; Hauggaard-Nielsen, H.; Thomsen, A.B. Potential bioethanol and biogas production using lignocellulosic biomass from winter rye, oilseed rape and faba bean. Biomass Bioenergy 2007, 31, 812-819. [CrossRef]

44. Lan, T.Q.; Lou, H.; Zhu, J.Y. Enzymatic saccharification of lignocelluloses should be conducted at elevated pH 5.2-6.2. Bioenergy Res. 2013, 6, 476-485. [CrossRef]

45. Hames, B.; Ruiz, R.; Scarlata, C.; Sluiter, A.; Sluiter, J.; Templeton, D. Preparation of Samples for Compositional Analysis; Laboratory Analytical Procedures, National Renewable Energy Laboratory: Golden, CO, USA, 2008; p. 1617, NREL/TP-510-42620.

46. Sluiter, A.; Hames, B.; Ruiz, R.; Scarlata, C.; Sluiter, J.; Templeton, D.; Crocker, D. Determination of Structural Carbohydrates and Lignin in Biomass; Laboratory Analytical Procedures, National Renewable Energy Laboratory: Golden, CO, USA, 2011; p. 18, NREL/TP-510-42618.

Sample Availability: Samples of the compounds are not available from the authors. 